\title{
Vietnamese Commercial Banks and Corporate Governance
}

\author{
E. Bace \\ Middlesex University, United Kingdom
}

\begin{abstract}
Objective - Corporate governance is a focus of bank managers and stakeholders, especially after the financial crisis. Contributing to firm and bank difficulties is weakness in managing internally and externally, making governance critical; even more so for banks which play a central role in the economy, allocating capital, lowering risk for businesses and individuals, and ensuring stability and sustainability. Bank failures in the crisis (2008-2016) highlighted governance and risk in developed nations and in developing ones, such as Vietnam. This paper studies governance in bank performance and risk, using theoretical frameworks and empirical study.

Methodology - Fundamental governance is reviewed, for banks in particular, in two widely used frameworks. Prior research relates bank performance (share return and return on assets, ROA), risk (capital adequacy ratio, CAR) and governance (board size, BS; number of committees, NC; independent directors to total, NID).

Findings - As our models show, NC and NID relate positively to bank performance. CAR has a positive link to governance.

Novelty - Our recommendation is that banks in Vietnam must have effective boards to boost performance.

Type of Paper: Empirical.

Keywords: governance; banking; crises; Vietnam; performance,

Reference to this paper should be made as follows: E. Bace. (2019). Vietnamese Commercial Banks and Corporate Governance, J. Fin. Bank. Review, 4 (2): 73-81 https://doi.org/10.35609/jfbr.2019.4.2(4)
\end{abstract}

JEL Classification: M14; D21; G21; G34

\section{Introduction}

In 2011, Vietnamese foreign-owned banks with financial strength were endowed the same rights as domestic banks. The industry became crowded, with market share harder to maintain. To develop sustainably, Vietnam's banks must improve management and governance, with focus on risk and international governance standards. IFC's survey (2011) showed most Vietnamese firms have "very basic knowledge of corporate governance".

\footnotetext{
${ }^{*}$ Paper Info: Received: March 18, 2019

Accepted: July 11, 2019

* Corresponding author: E. Bace

E-mail: e.bace@mdx.ac.uk

Affiliation: Middlesex University, United Kingdom
} 
Our study measures the relation between governance and performance in Vietnamese commercial banks. The topic's significance and proposals should contribute to better governance and performance in this area. The study covers the period 2008-2016. In the crisis, not only Vietnamese banks but global ones were seriously affected: steady falls in share price, bankruptcy of big banks occurred. Vietnamese exchanges were slammed; shares of banks and firms dropped; for some banks by as much as $50 \%$, raising big questions of governance.

There are studies on governance in Vietnam, especially for banks. This study tests the relation of ROA and governance, using regression analysis. Our dependent variable is ROA, and independent variables are $\mathrm{BS}, \mathrm{NC}$ and NID. Our second test is risk (CAR) and governance. Variables of return and CAR are obtained from Asian Development Bank (ADB, 2015) and annual reports.

\section{2- Literature review/Technique}

\subsection{Corporate governance definition}

Corporate governance varies in countries because of diverse legal systems, cultures, and market developments, where much research has typically focused. Corporate governance was defined as (Shleifer \& Vishny, 1997): "how finance suppliers to firms assure return on investment". Deeper insight is given by 'Principles of Corporate Governance' by the Organization for Economic Co-operation \& Development (OECD, 1999): "relations between management, shareholders, and stakeholders, systems for goals, attaining and monitoring same." Though similar, governance and management differ. Management uses tools to manage, governance provides a framework for transparency, accountability (Dieu \& Hau, 2014), and occupies a higher level: firms must be well governed to protect stakeholders and pursue firm goals.

Governance eludes definition due to diverse views under varied condition. Walker's three main elements (2009) are as follows:

Corporate governance relates to structure of deciding firm goals and methods of reaching them.

Corporate governance controls regulations among all stakeholders to resolve conflicts of interest between owners and managers.

Adopted governance principles in different countries are the result of different complex systems of rules, acts, norms, traditions and procedures.

Internally, governance represents internal commitments, agreements, relationship establishment, rights, obligations, roles and responsibilities of groups such as board of directors, executives, shareholders and minorities (Thanh \& Ha, 2016). Agreements are made by firm regulations, and labor rules. External rules/regulations support governance in pursuit of justice. Governance affects capital access (IFC, 2015). Accountability builds stakeholder trust. Cost of capital relies on risk, and investor perception; high risk, high cost of capital (low firm value). Good governance aids firms to raise needed funds (Dieu \& Hau, 2014): contributing to lower interest, availability of long-term credit, and high valuation.

Good governance helps firm reputation (Harrison, 2007). Well governed firms respect stakeholders, boosting reputation by transparency/accountability. Governance mitigates conflicts between managers and shareholders (La Porta et al., 2000). The latter focus on maximizing wealth, but executives may be more interested to protect their position. How shareholders want their investment managed may differ from managers; problems arise, through conflicts among shareholders due to owner diversity. The OECD (2004) lists 5 mitigants, namely: "1) hostile takeover, 2) concentration of ownership and control in big shareholders, 3) delegating partial control to big creditors, 4) board control of CEO, 5) aligning managers with shareholders through compensation". 


\subsection{Corporate mechanism}

Governance is internal and external (endogenous and exogenous; Thanh \& Ha, 2016). Firms work endogenously (Llewellyn \& Sinha, 2000) for accountability. Foremost here is the board who oversee the firm and bridge with the stakeholders. The board monitors the CEO on shareholders' behalf. Most research has focused on board composition and independence. Independent directors usually strengthen the board, boosting effectiveness. The more board independence, the more easily inadequate CEOs can be replaced. Other studies suggest no conclusive evidence on independence (Becht, 2007). External mechanisms regulate managers/directors, avoiding inequity, and intransparency (Thanh \& Ha, 2016); an external force with power to discipline besides the market.

\subsection{Agency theories and Stewardship theories}

Agency theory looks at principals and agents (shareholders and managers). Ownership and control differ; owners suffer from self-regarding agents. Often executives act in their own interest: such as power/job security/income, not long-term shareholder return (James \& Houston, 1995). Agency theory views such problems and risk attitudes. Issues arise, as owners cannot verify managers' motives. In early stages of economics, studies found managers not always acting for shareholders; incentive divergence raises costs (Ciancanelli \& Gonzalez, 2000). Agency theory tries to align interests in order to lower costs (Shankman, 1999); these are agency costs (Jensen \& Meckling, 1976; shareholders), agent cost (principals), residual loss: manager decisions versus what shareholders want.

In contrast to agency theory, stewardship conveys a duty to others based on the intent to honour contracted relationships. Stewardship (Hernandez, 2012) explains how individuals sacrifice their own interests for others. Most governance theories start from self-interest, but stewardship rejects this; managers seek other ends besides financial ones. Managers still must do well, raise profits, bringing shareholder returns (Binh \& Giang, 2012). The board must define manager roles and expectations, being goal-oriented, for manager ability and worth.

\subsection{Banks and corporate governance}

In financial markets, banks are prime intermediaries given their role in the market and economy. Bank governance is critical to prevent crises. Our first instruction in governance, global in scope, is the 1999 Basel framework, reviewed in 2006 based on 2004 OECD standards. This scheme instructs managers and boards, also mandating minimum capital to protect banks, and promote transparency, market discipline (Basel Committee, 2010). Management includes all parties in leading/monitoring operations to meet stakeholder needs (Basel, 1999). Most important is the board, appointed by shareholders. It is necessary (Gruening \& Bratanovic, 2003) to have a strong, independent and active board closely involved in bank activities. The board is responsible to oversee and support management, to examine recommendations before approving. Good controls allow them to identify and address concerns before major problems arise. Involved and active boards help banks survive if they assess problems and take action. Board roles have been widely studied, with a common focus on composition and independence. Composition and board size relate to an ability to monitor CEOs (Binh \& Giang, 2012; Yung, 2009). Other studies form opposite conclusions. Belkhir (2009) found no significant relation between board size and composition of banks and performance in a US study.

Good governance is structured between board, executives, staff and shareholders to pursue shareholder interests, factoring in all stakeholders. Relevant aspects are board size, committees, and director independence, which we use for hypotheses. Governance in 20 Vietnam banks is gauged in these variables. 
Banks are interested intermediaries, which explains the relation between governance and risk. Investors (Binh \& Giang, 2012) care about investment return but also how risk is distributed. Better governance raises expected return and improves risk management. Due to bank risks, governance outlines risk management in various ways. A common method is CAR (capital over risk-weighted assets). Performance and risk management interact, and both depend on governance. As risks are managed better, managers raise performance. Banks enjoy better reputation and public image to lower their cost of capital and other sources of funds. With good risk management, banks operate with lower capital (Serbee \& Alix, 2015). Costs are saved, and banks can invest in riskier projects to yield better returns.

There have been various studies on the topic: the influence of governance on performance and risk management. Black, Jang and Kim (2003) found a positive correlation. Klapper and Love (2003) examined 14 stock markets and found better governance had high correlation with performance and market value. Before the crisis of 1991, Japanese boards did not well monitor their banks, which operated poorly, up to the crisis. Afterwards, many directors were replaced, and bank performance improved (Christopher \& Terry, 2004), which depended highly on boards. Southeast Asian privatized banks (William \& Nghia, 2005) performed better with strict board control. Other studies suggest the opposite. Prowse (1997) found most governance failure was on the part of regulators, not boards. Simpson and Gleason (1999) found little effect of governance on performance.

In Vietnam, study of this relation has been relatively neglected. Most research has been done in US and Europe. As Vietnam is rapidly developing, affected seriously by the financial crisis, especially in banking, it is instructive to study the influence of governance on performance, to help banks achieve better performance.

\section{3- Methodology}

\subsection{Research hypotheses}

H1: Good corporate governance has a significantly positive impact on profitability of banks

H2: Good corporate governance significantly positively influences capital ratio of banks

\subsection{Research methodology}

Governance theories considered are agency theory, stewardship and stakeholder theory; this study focuses on the agency aspect, boards and performance of managers (agents), developed from theoretical governance frameworks (Macey \& O'Hara, 2001) and the Triangle Framework (Tandellilin et al., 2007). The regression model by Praptiningsih (2009) also partially applies. Macey and O'Hara focus on internal controls, relating to board (size, composition) and performance. The Triangle Framework explores three aspects: board, risk and performance.

\subsection{Data sample}

Stemming from the concentration of research methodology, variables for this study are summarized as follows:

Bank performance: ROA is used; ROE may be theclosest measure of shareholder investment return, but it is easy to manipulate equity accounts. ROA measures bank efficiency of assets to generate profit, dividing net profit by total assets. ROA is based on annual returns of 20 Vietnamese banks over nine years.

Risk management: our study uses CAR (ratio of bank capital to its risks, sum of tier 1 and 2 capital over risk weighted assets, Damodaran, 2004). ADB report (2015) and subsequent annual reports show CAR for Vietnam's banks 2008-2016. 
Board of directors: Measured by the following proxies:

Board size (BS): number of people elected by shareholders, collected from bank annual reports.

Board composition: NID. Independents have no material relation with firm or related persons besides sitting fee (Damodaran, 2004). This study tests NID versus ROA, , CAR.

Committees: NC. Committees of board members with specific duties play important roles in helping boards make decisions. In theory, there are at least four committees often appointed by firms, namely audit, remuneration, nomination and risk committee (Cadbury, 1992). Audit is charged with internal controls: approving financial statements and other documents before agreement by full board, communicating with external auditors, reporting to shareholders. This committee often consists of independent non-executive directors with at least one member having experience in finance. Remuneration decides executive compensation. Nomination committee identifies candidates for director and executive positions. Risk committee advises board on risk and strategy, considering board risk tolerance, and firm capacity to manage risks within agreed strategy.

\subsection{Population and sample}

At end 2016, 38 Vietnam commercial banks consisted of 5 state-owned, 33 joint-stock, 5 foreign-owned, and 5 joint-venture banks. We focus on the biggest 20 commercial banks, due to data limitations. Data are from 2008-2016. Regression examines the relation between governance indicators and performance. This methodology is used often in research testing the relation among variables (Binh \& Giang, 2012; Tsorhe et al., 2011). Ordinary least squares (OLS) is applied. Regression tests the relation with ROA, CAR, NID, NC. Equations are as follows:

$$
\mathrm{ROA}=\alpha^{*} \mathrm{BS}+\beta^{*} \mathrm{NC}+\mathrm{a}^{*} \mathrm{NID}+\text { intercept } \alpha
$$

$\mathrm{CAR}=\mathrm{y} 1 * \mathrm{BS}+\mathrm{y} 2 * \mathrm{NC}+\mathrm{y} 3 * \mathrm{NID}+$ intercept $\alpha$

Above, $\alpha$ is coefficient of BS and ROA, $\beta$ is coefficient of NC and ROA, $a$ is coefficient of NID and ROA, intercept $\alpha$ is model coefficient. For CAR model regression; yx is coefficient of variables and CAR, intercept $\alpha$ is model coefficient.

\section{4- Findings}

\subsection{Results}

Regression for ROA checked the relation between NIC, BS, NC and ROA of the 20 banks. Result of regression are as follows:

$$
\begin{array}{cccc}
\text { ROA } & =-0.005 * \mathrm{BS}+0.009 * \mathrm{NC}+0.91 * \mathrm{NID}+0.65 & \\
\mathrm{t} \text {-stat } & (-0.11) & (0.14) & (3.22)
\end{array}
$$

The result shows our first hypothesis to be valid, that good governance has a directly positive impact on ROA. Since R-squared is low, governance indicators have a positive effect on ROA but the influence is not strong, or significant. Next, the relation between CAR and BS, NC and NID is tested. The result is presented here:

CAR

$$
=-0.004 * \mathrm{BS}+0.002 * \mathrm{NC}+0.017 * \mathrm{NID}+0.16
$$

t-stat

$$
(-1.85) \quad(-0.85)
$$

$$
\mathrm{R} 2=4.04 \%
$$

$\mathrm{BS}$ also has a negative impact on CAR, not strong enough to have a big impact on CAR (R-squared only $4.04 \%)$.

\subsection{Discussion}


NC and NID have a positive relation with performance (ROA). Expected advantages to big boards are better advice and networks, and better decisions. Larger boards intuitively make better decisions with diverse abilities and experience. Not only promoting better engagement in discussions and decision-making, board diversity in theory helps minimize power in the hands of a small number of directors. Yet this view is not consistent; other studies, like ours, show a negative relation of these two variables (Belkhir, 2009), or statistical insignificance of BS on performance (Praptiningsih, 2009). Big boards bring advantages and disadvantages. Research suggests increase in BS leads to better performance, but too big a board has an opposite impact. Excessively big boards may make it more difficult and time consuming to make good decisions. Guest (2009) showed excessively big board's lead to a negative and inefficient relation between BS and performance. Many banks and firms succeed with small boards. Bank size has a big effect on the relation of BS and performance. The ideal number for boards differs based on firm size and regulation. Blenko et al. (2010) suggested optimal boards should have seven members. Takagi (2009) suggested at least three, no more than 15 . This implies no "one size fits all" due to differences in markets and nations. Optimal BS may be 7-10 depending on bank size and regulation.

Positive relation of NC and performance shows committees have strong governance roles. They help manage banks and shareholder communication. Yet in Vietnamese banks, they are less relevant, with a low coefficient between NC and performance. As with other banks in the world, Vietnam bank boards often have only the four committees listed above. Still some banks have one or two committees, normally remuneration and risk. In 2012, almost all Vietnam's banks had four committees or more, but not before 2012. Among the three variables, NID has the biggest impact on performance, with the highest coefficient. NID affects performance differently. The more board independence, the better it can operate. Banks with more independents make better decisions based on shareholder interest. This reduces conflicts between shareholders and agents. The study highlights the importance of NID in boards statistically as a rise in NID raises ROA and share return. Some banks still lack independents, but are few, often not operating well since boards may act based on own interests rather than shareholders. Conflicts between agents and shareholders rise with non-independent directors.

In our second model, all three independent variables have low CAR relation; this is reasonable in short run as this work covers 9 years, including financial crisis. The higher the CAR, the safer the bank, with equity risk reduced, and lower expected ROE. In theory, higher CAR works for better governance. Yet recent studies show in the financial crisis, capital composition undermined owner incentives; banks paid dividend and issued capital as debt and preferred stock, unbalancing priority of obligation, shifting risk (Acharya, 2009). In crisis, good governance led not to higher CAR. Investors like risk as higher risk implies higher return; lower CAR likely in the short term attracts investment. Besides raising equity, banks may raise CAR by reducing risk-weighted assets. This lowers risk, unattractive to risky investors. Banks with good risk management likely have less capital to reduce cost of capital. This capital is invested in risky projects with good returns. Banks with good governance can afford low CAR, thus the inverse relation to CAR and governance, which studies show (Binh \& Tam, 2014). Tshorhe et al. (2011) show better governance in banks with less capital, subject to minimum requirement. Studies also suggest this may not hold long term as good capital structure and CAR can raise public trust.

\section{5- Conclusion}

This work studied the relation in governance and performance (ROA) and risk (CAR). Different variables tested were BS, NC and NID. Vietnam's banks are at the very start of governance, examined in this paper, with successful regression models. A positive relation is noted in performance and governance. NID coefficient is highest, implying this most affects performance; NID rise grows ROA. This validates our hypothesis: good governance has significant positive impact on performance. Our second hypothesis also valid, indicating better governance could raise CAR though slightly; likely this is true short term as study 
covers 2008-2016. Longer term, the result may differ. In short, governance has neither positive nor negative significant effect on bank CAR.

As policy recommendation, banks must ensure boards are fully qualified, and understand governance. Boards must not be swayed by managers or outside concerns. They must protect stakeholder interests; in Vietnam up to now, only main shareholders have been considered. We recommend raising NID and NC. Banks must promote risk management, and empower boards with risk committees, eg internal audit. Committees must be independent, objective in assessing through internal controls with board/managers. Clear policies/processes ensure timely action against risk. Vietnamese banks can learn from foreign banks with risk experience.

\section{References}

Acharya, V., Carpenter, J., Gabaix, X., John, K., Richardson, M., Subrahmanyam, M., \& Zemel, E. (2009). Corporate governance in the modern financial sector. Restoring Financial Stability, 185-196, https://onlinelibrary.wiley.com/doi/abs/10.1002/9781118258163\#page=193

Adams, R.B. and Mehran, H. (2008) 'Corporate Performance, Board Structure and Their Determinants in the Banking Industry', Federal Reserve Bank of New York Staff Reports, No.330, revised October 2011, https://papers.ssrn.com/sol3/papers.cfm?abstract_id=1150266

Anasary, O. (2015) 'Determinants of capital adequacy ratio: An empirical study on Egyptian banks', Journal of Corporate Ownership and Control, Vol. 13 (1), pp. 806-816, https://papers.ssrn.com/sol3/papers.cfm?abstract_id=2708603

Aspal, P. K. and Nazneem, A. (2014) 'An empirical analysis of capital adequacy in the Indian private sector banks', American Journal of Research Communication, Vol. 2 (11), pp.28-42

Bank for International Settlements, (2000) Principles for the Management of Credit Risk, (Online), Available at: http://www.bis.org/publ/bcbs54.pdf [Accessed on 16 July 2018]

Basel Committee on Banking Supervision (2006) Enhancing Corporate Governance for Banking Organizations, (Online), Available at: http://www.bis.org/publ/bcbs122.htm [Accessed on 14 July 2018]

Becht, M. (2007) Corporate Law and Governance, (Online), Available at: https://www.gsb.columbia.edu/faculty/pbolton/BBRLE.pdf [Accessed on 10 July 2018]

Belkhir, M. (2009). Board of directors' size and performance in the banking industry. International Journal of Managerial Finance, 5(2), 201-221, https://doi.org/10.1108/17439130910947903

Binh, D. and Tam, D. (2014) 'Corporate governance and bank performance - An International Comparison: Vietnam and Malaysia', Available at: http://papers.ssrn.com/sol3/papers.cfm?abstract_id=2539948

Binh, D. and Thomas, A. (2014) 'Capital adequacy and banking risk - An empirical study of Vietnamese banks', (Online), Available at: http://papers.ssrn.com/sol3/papers.cfm?abstract_id=2524233 [Accessed on: 16 July 2018]

Black, B., Jang, H. and Kim, W. (2003) 'Does governance affect firm value?', Working Paper ,U. Amsterdam

Blenko, M. W., Mankins, M. C., \& Rogers, P. (2010). Decide \& deliver: 5 steps to breakthrough performance in your organization. Harvard Business Press.

Cadbury, A. (1992). Report of the Committee on the financial aspects of Corporate Governance, Gee \& Co. Ltd., London, United Kingdom.

Caprio, G., \& Levine, R. (2002). Corporate governance in finance: Concepts and international observations. Financial sector governance: The roles of the public and private sectors, 17-50, http://citeseerx.ist.psu.edu/viewdoc/download?doi=10.1.1.19.254\&rep=rep1\&type=pdf

Christopher, J. (2008) 'Pure vs speculative risks', (Online), Available at: http://www.mynewmarkets.com/articles/92443/pure-vs-speculative-risk [Accessed on 03 July 2018]

Anderson, C. W., \& Campbell II, T. L. (2004). Corporate governance of Japanese banks. Journal of Corporate Finance, 10(3), 327-354, https://doi.org/10.1016/S0929-1199(03)00029-4

Ciancanelli, P. and Gonzalez, J. (2000) 'Corporate governance in banking: A conceptual framework', (Online), Available at: http://papers.ssrn.com/sol3/papers.cfm?abstract_id=253714 [Accessed July 8, 2018]

Damodaran, (2004) Applied Corporate Finance, published by John Wiley \& Sons Inc., New York

Dieu, L and Hau, N. (2014) 'New thinking about corporate governance in Vietnamese commercial banks', State Bank of Vietnam, Available at: http://dl.ueb.vnu.edu.vn/handle/1247/10553 
Fan, P.S. (2004) "Review Of literature and empirical research on corporate governance", Financial Services Group Training Unit Monetary Authority of Singapore

Van Greuning, H., \& Brajovic Bratanovic, S. (2009). Analyzing Banking Risk a Framework for Assessing Corporate Governance and Financial Risk. The World Bank.

Guest, P. (2009) 'Impact of board size on performance', European Journal of Finance, Vol 15(4), pp. 385-404, https://doi.org/10.1080/13518470802466121

Haeley, J. (2001) 'Financial instability and the central bank - international evidence', Centre for Central Bank Studies, Bank of England

Harrison, K. (2007) 'Why good corporate reputation is important to your organization', Available at: http://jobfunctions.bnet.com/abstract.aspx?scname=Interpersonal+Communication\&docid=263774

Hermalin, B.E. and Weisbach, M.S. (1991) 'The effect of board composition and direct incentives on firm performance', Journal of Financial Management, Vol. 20, pp. 101-112

Hernandez, M. (2012) 'Toward an understanding of the psychology of stewardship', Academic of Management Review, Vol. 37 (2), pp. 172-193, https://doi.org/10.5465/amr.2010.0363

Houston, F. and James, C. (1995) 'CEO compensation and bank risk: Is compensation in banking structured to promote risk taking?', Journal of Monetary Economics, Vol.36, pp. 405-431, https://doi.org/10.1016/0304-3932(95)01219-2

International Finance Corporation (IFC), Global Corporate Governance Forum (GCGF) and State Securities Commission (SSC), (2011), 'Corporate Governance Scorecard Report', Washington

Jensen, M. and Meckling, W. (1976) 'Theory of the Firm: Managerial Behavior, Agency Costs and Ownership Structure', Available at: http://papers.ssrn.com/sol3/papers.cfm?abstract_id=94043

Klapper, L. and Love, I. (2003) 'Corporate governance investor protection, and performance in emerging markets', Journal of Corporate Finance, Vol.10, pp.703-728

La Porta, R., Lopez-de-Silanes, F., Shleifer, A., \& Vishny, R. (2000). Investor protection and corporate governance. Journal of financial economics, 58(1-2), 3-27, https://doi.org/10.1016/S0304-405X(00)00065-9

Llewellyn, D. and Sinha, R. (2000) 'Monitoring and control of banks: The role of regulation and corporate governance', Corporate Governance in Banking \& Finance, McGraw-Hill Publishing Co. Ltd., New Delhi

Macey, J. \& O’Hara, M. (2001) 'Bank Corporate Governance', Federal Reserve Bank of NY Economic Policy Review OECD (2004) OECD Principles of Corporate Governance, Paris

Praptiningsih, M. (2009). Corporate governance and performance of banking firms: evidence from Indonesia, Thailand, Philippines, and Malaysia. Journal of Management and Entrepreneurship, 11 (1), 94-108, https://doi.org/10.9744/jmk.11.1.pp.\%2094-108

Prowse, S.(1997) 'Corporate control in banks', Journal of Financial Research, Vol. 20(4), pp. 509-27, https://doi.org/10.1111/j.1475-6803.1997.tb00263.x

Serbee, D. and Alix, M. (2015) 'At a crossroad? Regulatory capital and operational risk', Available at: https://www.theclearinghouse.org/publications/2015/2015-q2-banking-perspective/operational-risk

Shankman, N. (1999) 'Reframing the debate between agency and stakeholder theories of the firm', Journal of Business Ethics, Vol. 19(4), pp. 319-334, https://link.springer.com/article/10.1023/A:1005880031427

Shleifer, A. and Vishny, R. (1997) 'Survey of corporate governance', Journal of Finance, Vol.52, pp. 737-83

Simpson, W.G. and Gleason, A.E. (1999) 'Board structure, ownership. and financial distress in banking firms', International Review of Economics and Finance, Vol. 8(3), pp. 281-292, https://doi.org/10.1016/S1059-0560(99)00026$\mathrm{X}$

Takagi, G. (2009), 'Number of Directors - What's the best practice?', (Online), Available at: http://www.nonprofitlawblog.com/number-of-directors-whats-the-best-practice/ [Accessed on 03 Sep 2018]

Tandelilin, E., Kaaro, H., Mahadwartha, P. A., \& Supriyatna, S. (2007). Corporate governance, risk management and bank performance: Does type of ownership matter. EADN individual research grant project, 34, 115-118.

Thanh, P. and Ha, D. (2016) 'Corporate governance and operational risk management in Vietnamese commercial banks', (Online), Available at: http://huvien.vcef.edu.vn/doc/quan-tri-cong-ty-va-quan-ly-rui-ro-hoat-dong-tai-cacngan-hang-thuong-mai-viet-nam-362599.html [Accessed on 15 July 2018]

Tsorhe, J. S., Aboagye, A. Q., \& Kyereboah-Coleman, A. (2011). Corporate governance and bank risk management in Ghana. University of Ghana Business https://pdfs.semanticscholar.org/420e/535a5c6b4def3494ae27d4d57ed145091ed3.pdf

Tu, T. and Khanh, P. (2012) 'Corporate governance practices - Case studies of Vietnamese banks', (Online), Available at: http://papers.ssrn.com/sol3/papers.cfm?abstract_id=2202601 [Accessed on: 30 June 2018] 
Walker, D. (2009) 'Review of governance in UK banks and other financial industry entities', Available at: http://webarchive.nationalarchives.gov.uk/+/http:/www.hm-treasury.gov.uk/d/walker_review_261109.pdf

William, J. and Nghia, N. (2005) 'Financial liberalization, crisis, and restructuring: Comparative study of bank performance and bank governance in South East Asia', Journal of Banking \& Finance, Vol. 29, pp. 2119-2154, https://doi.org/10.1016/j.jbankfin.2005.03.011

Yung, M. (2009) 'Relation between corporate governance and bank performance in Hong Kong', Available at: http://www.sciencepublishinggroup.com/journal/paperinfo.aspx?journalid=171\&doi=10.11648/j.jfa.2013 